\title{
Morphological variation in two genetically distinct groups of the golden-striped salamander, Chioglossa lusitanica (Amphibia: Urodela)
}

\author{
J. Alexandrino, ${ }^{1,2}$, N. Ferrand ${ }^{1,2}$, J.W. Arntzen ${ }^{1,3}$ \\ ${ }^{1}$ CIBIO Centro de Investigação em Biodiversidade e Recursos Genéticos, Campus Agrário de Vairão, 4485-661 \\ Vairão, Portugal; ${ }^{2}$ Departamento de Zoologia e Antropologia, Faculdade de Ciências, Universidade do Porto, \\ Praça Gomes Teixeira, 4099-002 Porto, Portugal; ${ }^{3}$ Zoology Department, National Museum of Natural His- \\ tory - Naturalis, P.O. Box 9517, 2300 RA Leiden, The Netherlands
}

Corresponding author: João Alexandrino

Present address: Departamento de Zoologia, Instituto de Biociências, Universidade Estadual Paulista, 13506-900 Rio Claro,São Paulo,Brazil,e-mail: jalex@rc.unesp.br

Key words: Amphibia, Chioglossa lusitanica, clinal variation, colour pattern, golden-striped salamander, morphometrics

\begin{abstract}
Morphometric and colour pattern variation in the endemic Iberian salamander Chioglossa lusitanica is concordant with the genetic differentiation of two groups of populations separated by the Mondego river in Portugal. Salamanders from the south have shorter digits than those from the north. Clinal variation with a south to north increase in limb, toe and finger length was found superimposed on this dichotomy, resulting in stepped clines for characters describing appendage size. Genetic variability was paralleled by colour pattern variability in the contact zone and in northern populations. To explain the observed parallels we invoke the neutral processes of vicariant isolation, admixture in a secondary contact zone, genetic drift in addition to selection acting along an environmental gradient. Morphological constraints imposed by a highly specialized ecological niche may explain why the genetic subdivision of $C$. lusitanica since the early Pleistocene has remained fairly cryptic.
\end{abstract}

\section{Contents}

Introduction 213

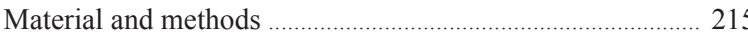

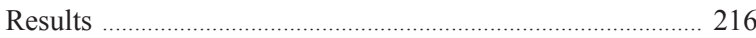

Morphometrics …………………………………………........ 216

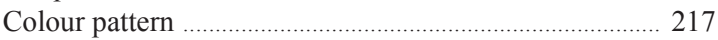

Testing causal hypotheses …………………………............ 218

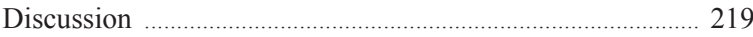

Acknowledgements ........................................................... 220

References ……................................................................... 220

\section{Introduction}

The discovery of genetically differentiated groups of populations within species raises the question of how influential genetic isolation has been in generating phenotypic diversity. Since morphological traits are products of both genetics and the environment (see e.g. Schluter, 2000) it is relevant, from an evolutionary perspective, to determine whether morphological variation reflects historical isolation or local adaptation despite recurrent gene flow. To distinguish between these non-exclusive hypotheses it is important to study a variety of traits. Differentiation arising from historical isolation of populations (i.e. with the stochastic effects of mutation and drift acting independently in isolated populations) will likely generate parallel patterns across characters of different nature, e.g. genetics and morphology, whereas adaptation across environmental selection gradients will not, or not necessarily so. Organismal constraints involving plasticity and autopoiesis may however cause morphological stasis despite considerable levels of genetic and environmental change through evolutionary time, such as in Plethodontid salamanders (Wake et al., 1983; see also Larson, 1984). In the case of cryptic closely related lineages one way of testing hypotheses on the extent and nature of phenotypic diversity has been the multivariate statistical analysis of morphometric data (e.g. Good and Wake, 1992; Arntzen and Sket, 1997; Puorto et al., 2001).

The golden-striped salamander, Chioglossa lusitanica Bocage 1864, is a streamside species inhabiting low and medium elevation mountainous areas in the northwest of the Iberian Peninsula (Fig. 1). 


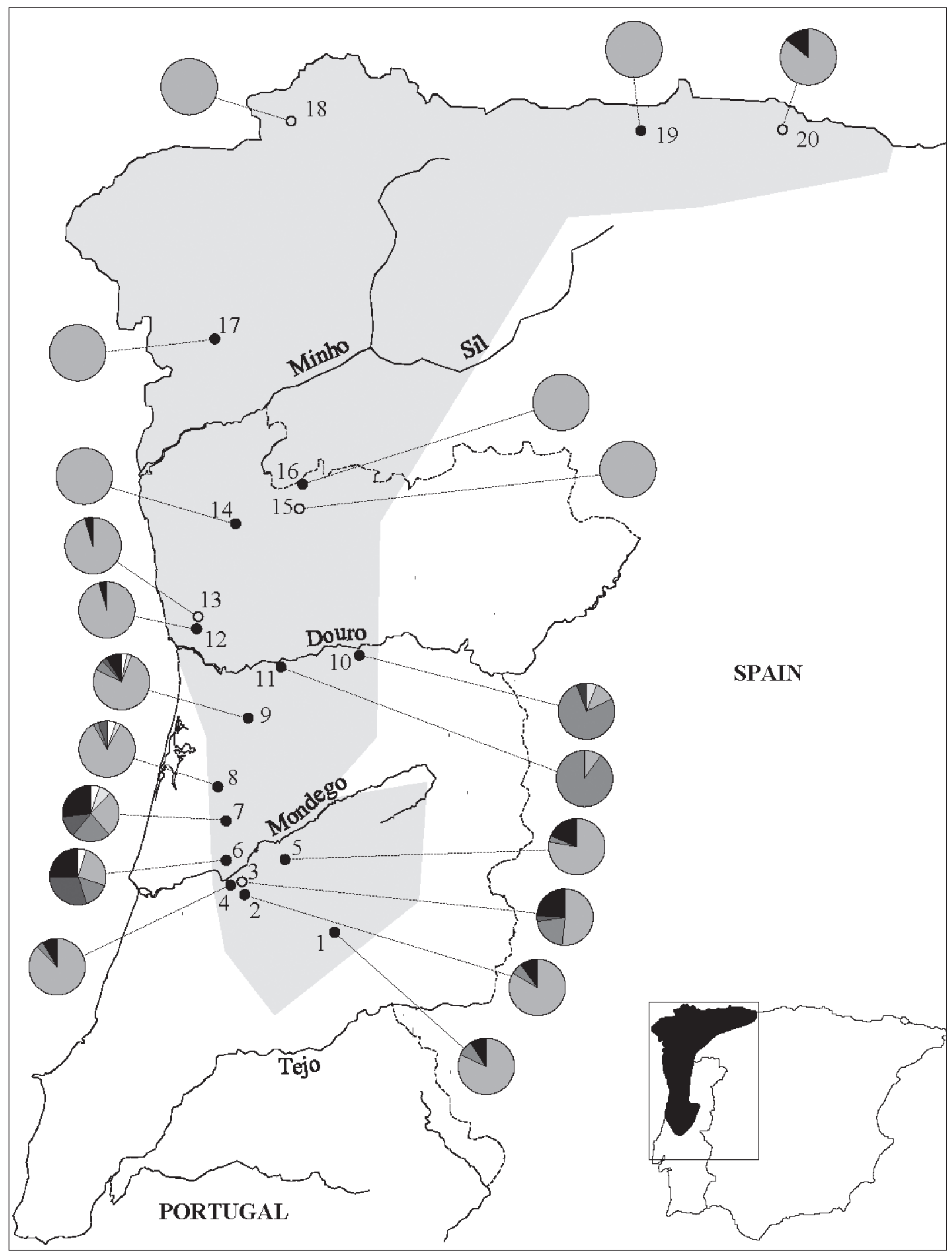


Alexandrino et al. (1997, 2000, 2002) analyzed allozyme and mitochondrial DNA variation and uncovered two genetically distinct groups of populations geographically separated by the river Mondego in central Portugal (group 1 south of the river and group 2 north of the river). The two groups represent lineages that separated in the early Pleistocene, probably as a result of climate change in combination with local environmental conditions and formed a secondary contact zone in postglacial times (Sequeira et al., 2005). The northern part of the present range was colonized from a refugium located in between the Mondego and the Douro. Major rivers such as the Douro and, more to the north, the Minho acted as barriers to dispersal, lowering genetic diversity through sequential bottlenecking (Alexandrino et al., 2000).

Morphological variation in C. lusitanica was first observed by Vences (1990), but with only three populations studied in Portugal, robust spatial patterns could not be discerned. We here describe morphological variation within $C$. lusitanica to investigate if i) the diversification of $C$. lusitanica in two population groups and ii) the decrease of genetic diversity in recently colonized areas, have been paralleled by morphological variation. If genetic drift has been underlying morphological evolution we expect concordance between genetic and morphological patterns of variation. Conversely, non-concordance between genetics and morphology is expected if directional selection and epistasis have been major sources of morphological variation (see Reed and Frankham, 2001). We specifically test morphometric and colouration pattern variation across the species' range against the causal hypotheses of i) vicariance of groups 1 and 2 and ii) isolation by distance. Latitu-

Fig. 1. The distribution of Chioglossa lusitanica in the northwestern Iberian Peninsula (shaded area, from Arntzen, 1999) and the study localities. (1) Muradal, Foz de Giraldo (MU). (2) Lousã, C. Pêra (LCP). (3) Lousã, Fiscal (LFI). (4) Lousã, Vilarinho (LVI). (5) Açor, Margaraça (AC). (6) Várzeas (VA). (7) Buçaco (BU). (8) Saide (SA). (9) Covelo (C). (10) Tarouca (T). (11) Montemuro (M). (12) Valongo, Silveirinha (VSI). (13) Valongo, Águas Férreas (VAF). (14) Bom Jesus (B). (15) Cabreira (CA). (16) Gerês (G). (17) Pontevedra (PO). (18) Caaveiro (CAV). (19) Salas (SAL). (20) Cuera (CU). Solid dots denote populations for which genetic data are available (Alexandrino et. al., 2000). Pie diagrams represent colour pattern classes (see text for details): $\square-0, \square-1$, $\square-2, \square-3, \square-4, \square-5$. dinal increase/decrease in morphological trait diversity is examined against causal hypothesis of i) genetic heterozygosity ii) hybrid origin of populations and iii) geographic distance between populations.

\section{Material and methods}

A total of 420 adult Chioglossa lusitanica was collected from 20 localities (Fig. 1). Sample sizes ranged from 7 to 51. For each individual the dorsal colouration pattern was classified on two accounts i) prominence of colour spots on the dorsum and ii) proportion of colour patches relative to colour stripes, with six ranked (0-5) colour pattern types as follows: type 0 , coloured patches absent i.e., melanic; type 1 , few coloured patches arranged into incomplete stripes; type 2, two uninterrupted coloured stripes, separated by a dark area of approximately the same width (typical pattern); type 3, stripes wider; type 4, central area with coloured patches diffusely distributed; and type 5, central area with coloured patches densily packed in a mosaic pattern. For a general impression of colour pattern variation in C. lusitanica see Vences (1990). Seven morphometric measurements were taken on 275 individuals representing all populations except nos. 14 and 17: snout-vent length (SVL), head (snout-gular) length (HL), head width (HW), forelimb length (FLL), hindlimb length (HLL), third finger length (TFL) and fourth toe length (FTL) (Fig. 2). Measurements were taken to the nearest $0.1 \mathrm{~mm}$ with digital callipers by a single observer (JA) on animals anaesthetized with MS-222. Subsequently, salamanders were released on their localities of origin.

Morphometric data were log-transformed to reduce deviations from normality and distortion effects caused by allometric relationships. Population means were compared by multivariate analysis of variance (MANOVA) with the variable 'sex' nested under the variable 'locality'. All measurements showed significant differences between populations (Wilks' lambda $=0.098, P<0.001$; univariate results all with $P<0.001)$ and HL and FLL showed significant differences between sexes (respectively, $\mathrm{F}$ $=2.865, \mathrm{P}<0.001$ and $\mathrm{F}=4.437, \mathrm{P}<0.001)$. Subsequent morphometric analyses were performed for males and females separately by principal component analysis (PCA) with the software package 


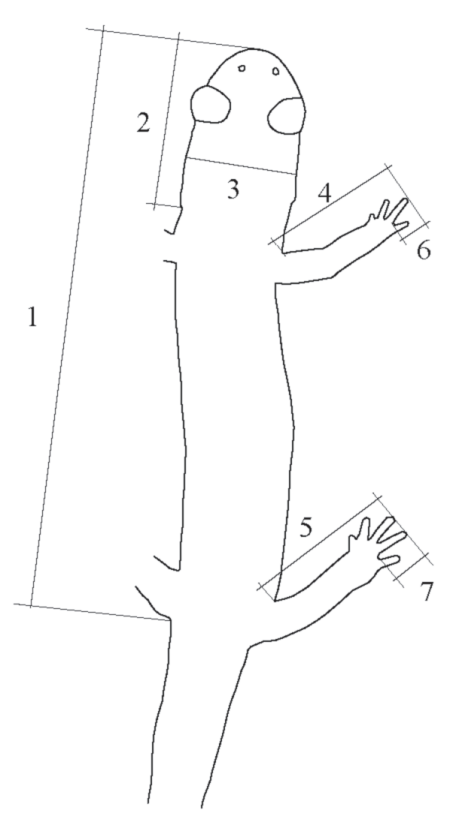

Fig. 2. Morphometric measurements taken in 18 populations of Chioglossa lusitanica: (1) SVL, snout-vent length. (2) HL, head (snout-gular) length. (3) HW, head width. (4) FLL, forelimb length. (5) HLL, hindlimb length. (6) TFL, third finger length. (7) FTL, fourth toe length.

Statistica/w 4.5 (StatSoft, 1993). Following confirmation that size explained most of the observed variability (first axis explained c. $54 \%$ of the variance, with variable negative correlations of 0.65 0.83 ), the residuals of the regression of $\log <$ character $>$ against $\log \mathrm{SVL}$ were used, hereafter denoted by the symbol \# linked to the variable name. Trend surface maps were generated by kriging under default settings in Surfer 6.0 (Golden Software, 1996) geostatistical software.

Table 1. Factor loadings for the first and second Principal Components axis for six size adjusted (\#) morphometric measurements taken in 18 populations of Chioglossa lusitanica.

\begin{tabular}{lcrrr}
\hline & \multicolumn{3}{l}{ Females } & \multicolumn{3}{c}{ Males } \\
\cline { 2 - 5 } Variables & PCA 1 & PCA 2 & PCA 1 & PCA 2 \\
\hline Head length (HL\#) & 0.195 & 0.710 & 0.483 & 0.536 \\
Head width (HW\#) & 0.157 & 0.800 & 0.158 & 0.841 \\
Forelimb length (FLL\#) & 0.762 & -0.193 & 0.800 & -0.248 \\
Hindlimb lenth (HLL\#) & 0.845 & -0.109 & 0.803 & -0.331 \\
Third finger length (TFL\#) & 0.834 & 0.008 & 0.772 & -0.102 \\
Fourth toe length (FTL\#) & 0.885 & -0.038 & 0.805 & 0.007 \\
Variance explained & $47.3 \%$ & $20.2 \%$ & $46.5 \%$ & $19.6 \%$ \\
\hline
\end{tabular}

Morphological differentiation, expressed by pairwise euclidean distances between population means (both of size adjusted variables and scores of size adjusted PCA), was tested against the independent variables geographic distance (measured on 1:100,000 maps) and group membership by partial Mantel tests (RT 2.0; Manly, 1996), with 10000 randomizations. Similarly, morphometric variability (population distances calculated from the variance on the PCA axes) and colour pattern variability (population distances calculated from the coefficient of variation) were tested against genetic heterozygosity and hybridity (Alexandrino et al., 2000). Hybridity distinguished populations located within and outside the putative contact zone (nos. 3, 4, 6 and 7 versus the others). To evaluate the a posteriori classification of individuals in each population to either group 1 or group 2, Discriminant Analysis (DA) was performed on size adjusted morphological measurements with Statistica/w 4.5 (StatSoft, 1993). The hypothesis of association between morphological variation and latitude was tested through linear regression of PCA1 scores with distance along a south to north axis.

\section{Results}

\section{Morphometrics}

The first and the second PCA axes explained, respectively, ․ $47 \%$ and ‥ $20 \%$ of the variance, for both males and females (Table 1). The first axis had high factor loadings for limb and digit variables (0.76 to $0.89)$. The second axis had high loadings for head length and head width (0.54 to 0.84$)$. Hence, the variation observed for head shape and the size of the extremities was largely independent. Mean population factor scores for the first axis increased from south to north, reflecting an increase in relative size of limbs and digits (Figs. 3 and 6). Mean factor scores for the second axis did not show any readily interpretable geographic pattern (Fig. 3).

\section{Colour pattern}

Colour pattern type 2 was the most common one in all examined populations, except for populations 10 and 11 in which type 3 was most frequent (Fig. 1). 
Females

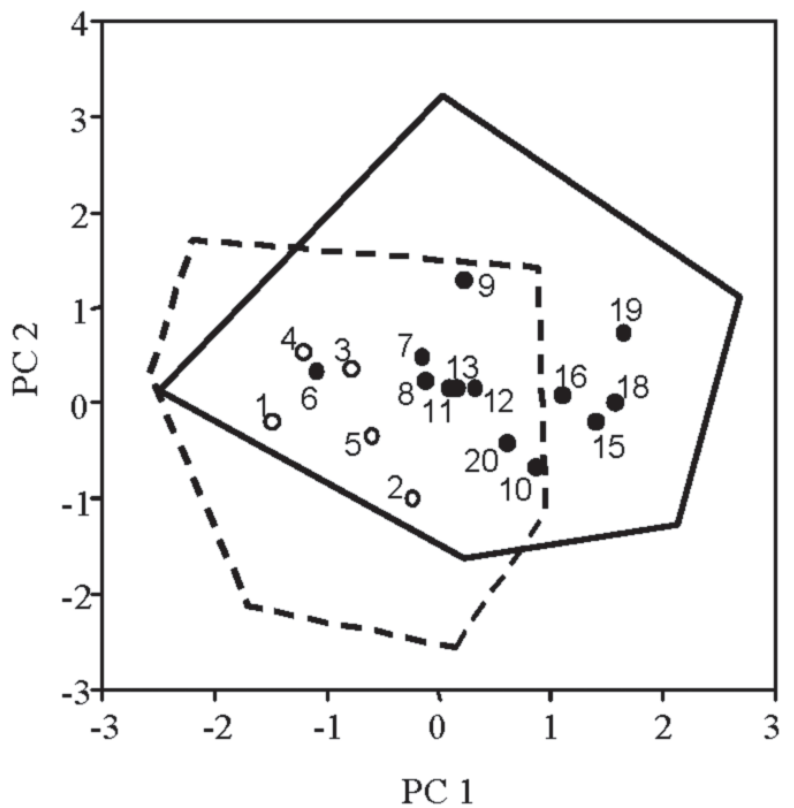

Fig. 3. First two axes from PCA of six size adjusted morphometric variables in 18 populations of Chioglossa lusitanica. Population centroids and minimum convex polygons enclosing individual factor scores for group 1 and group 2 populations. Open dots and dashed polygon lines represent southern 'group 1' populations; solid dots and uninterrupted polygon lines represent northern 'group 2' populations.

Type 3 was present in all populations south of the Douro River. Other pattern types were present in some populations and not in others. Types other than type 2 were absent north of the Douro, with the exception of type 4 that was present, albeit at low frequency, in populations 12,13 and 20.

\section{Testing causal hypotheses}

Scores on the first PCA axis were significantly associated with geographic distance, group membership (Table 2) and latitudinal distance (Fig. 5). Scores on the second axis were not associated with either of the

Fig. 4. Means and standard deviations for the a posteriori probability $(\mathrm{P})$ of classification of individuals in each population to northern group 2, from Discriminant Analysis of six size adjusted morphometric variables in 18 populations of Chioglossa lusitanica.
Males
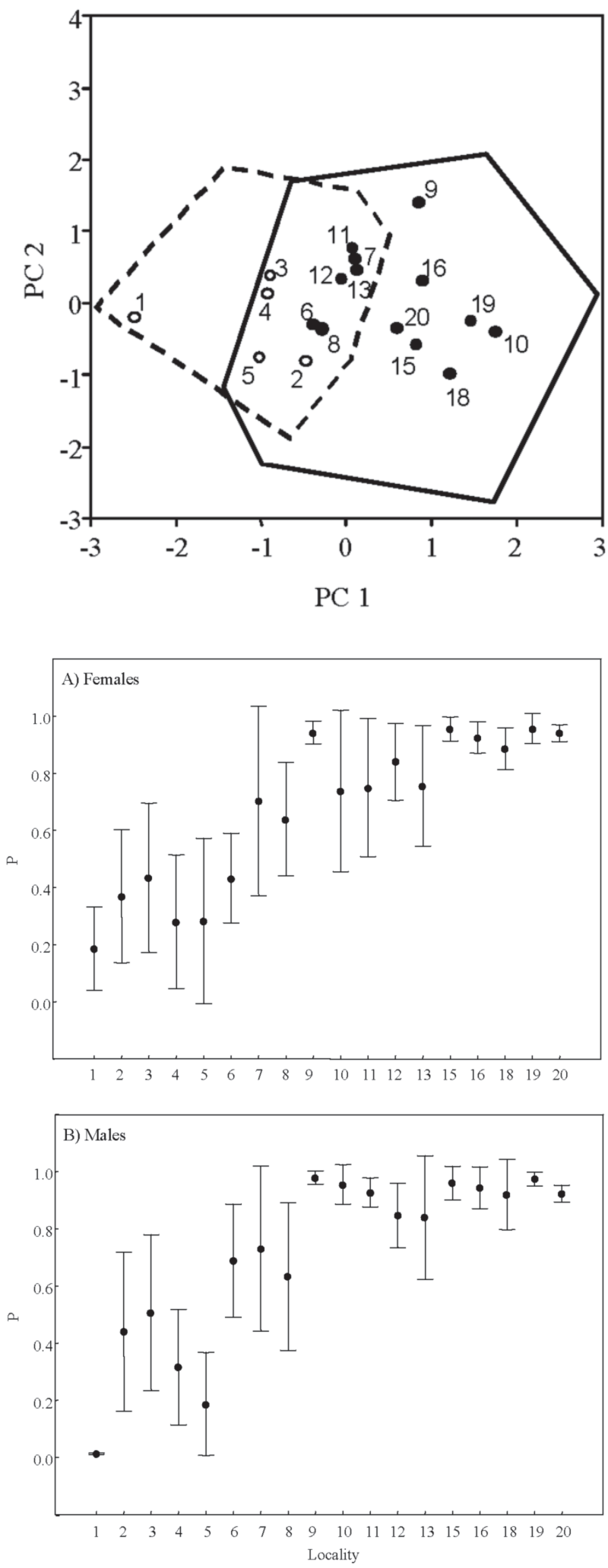

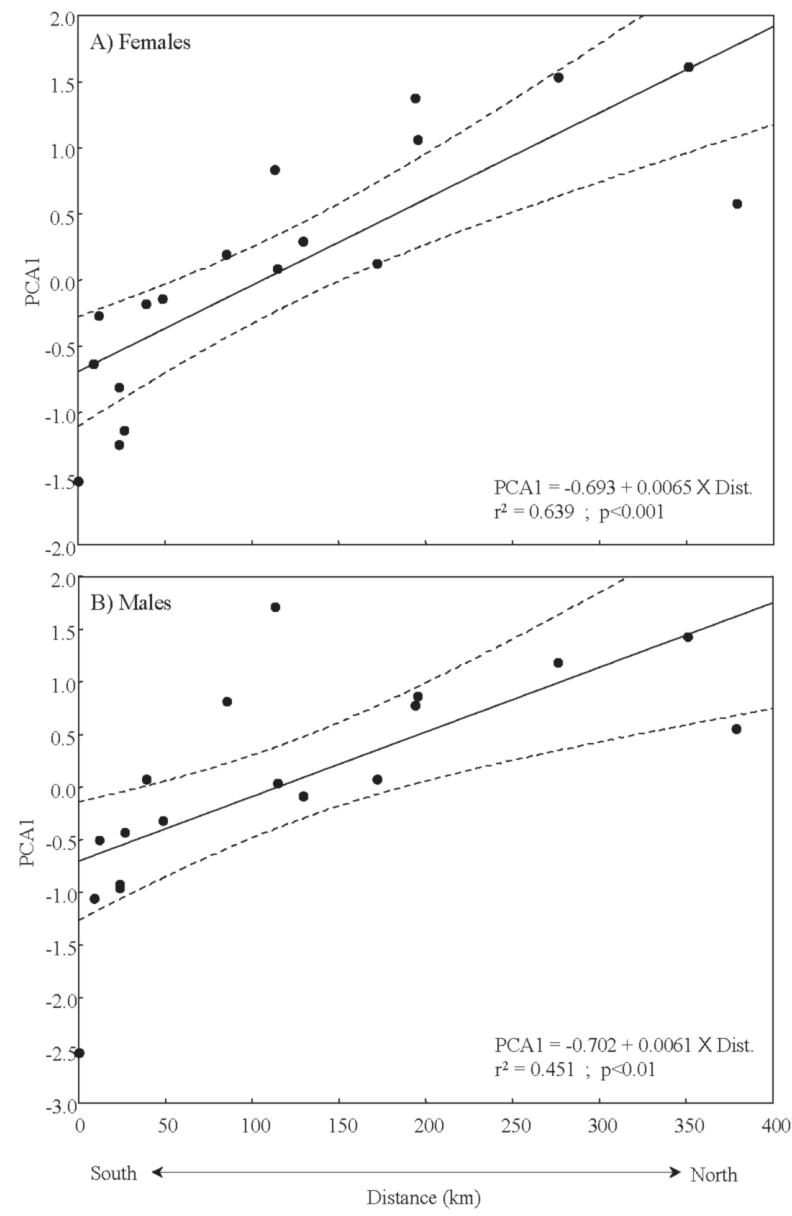

Fig. 5. Regression of mean factor scores of the first Principal Component axis of 18 populations of female Chioglossa lusitanica against distance along a south-north axis.

independent variables (Table 2). Classification of individuals (both females and males) in group 2, following DA, increased gradually from south to north (Fig. 4). In females, head length and head width were associated with geographic distance and group membership, respectively. Size of the extremities was associated with geographic distance, with the exception of FLL\# in males. Digit length and HLL\# in males were also associated with group membership. Colour pattern was associated to neither geographic distance or group membership. Morphometric variability was not associated with any of the formulated independent variables (Table 3). Colour pattern variability was associated with hybridity and not with geographic distance or heterozygosity. Additionally,
Table 2. Partial Mantel test results for association between morphological differentiation across 18 populations of Chioglossa lusitanica versus geographic distance and group membership (see text for details). Dependent variables are A) top panel, the first and second PCA-axis and B) lower panel, individual size adjusted (\#) morphometric variables and colour pattern.

\begin{tabular}{lll}
\hline & \multicolumn{2}{l}{$\begin{array}{l}\text { Causal hypothesis } \\
\text { (independent variables) }\end{array}$} \\
\cline { 2 - 3 } $\begin{array}{l}\text { Morphological distance } \\
\text { (dependent variable) }\end{array}$ & $\begin{array}{l}\text { distance } \\
\text { deophic }\end{array}$ & $\begin{array}{l}\text { Group } \\
\text { membership }\end{array}$ \\
\hline A) PCA 1 (females) & $* * *$ & $* *$ \\
PCA 1 (males) & $\mathrm{ns}$ & $* * *$ \\
PCA 2 (females) & $\mathrm{ns}$ & $\mathrm{ns}$ \\
PCA 2 (males) & $*$ & $\mathrm{~ns}$ \\
B) HL\# (females) & $\mathrm{ns}$ & $\mathrm{ns}$ \\
HL\# (males) & $\mathrm{ns}$ & $\mathrm{ns}$ \\
HW\# (females) & $\mathrm{ns}$ & $* *$ \\
HW\# (males) & $* * *$ & $\mathrm{~ns}$ \\
FLL\# (females) & $\mathrm{ns}$ & $\mathrm{ns}$ \\
FLL\# (males) & $* * *$ & $\mathrm{~ns}$ \\
HLL\# (females) & $*$ & $\mathrm{~ns}$ \\
HLL\# (males) & $*$ & $*$ \\
TFL\# (both sexes) & $* *$ & $* * *$ \\
FTL\# (both sexes) & $\mathrm{ns}$ & $* * *$ \\
\hline Colour pattern (both sexes) & $\mathrm{ns}$ \\
\hline ns - not significant, $*$ - $<<0.05, * *-\mathrm{p}<0.01, * * * ~$ & $\mathrm{p}<0.001$.
\end{tabular}

Table 3. Partial Mantel test results for association between morphological variability across 18 populations of Chioglossa lusitanica versus geographic distance, heterozygosity and hybrid versus non-hybrid population status.

\begin{tabular}{|c|c|c|c|}
\hline \multirow{2}{*}{$\begin{array}{l}\text { Morphological } \\
\text { variability distance } \\
\text { (dependent variable) }\end{array}$} & \multicolumn{3}{|c|}{$\begin{array}{l}\text { Causal hypothesis } \\
\text { (independent variables) }\end{array}$} \\
\hline & $\begin{array}{l}\text { Geographic } \\
\text { distance }\end{array}$ & Heterozygosity & Hybridity \\
\hline PCA1 (females) & ns & ns & ns \\
\hline PCA1 (males) & ns & ns & $\mathrm{ns}$ \\
\hline PCA2 (females) & ns & ns & ns \\
\hline PCA2 (males) & ns & ns & ns \\
\hline $\begin{array}{l}\text { Colour pattern } \\
\text { (both sexes) }\end{array}$ & ns & ns & $* *$ \\
\hline
\end{tabular}

a trend was observed for colour pattern variability to decrease from south to north in group 2 populations (Fig. 1).

\section{Discussion}

Morphometric variation in the endemic Iberian salamander Chioglossa lusitanica was found to be 


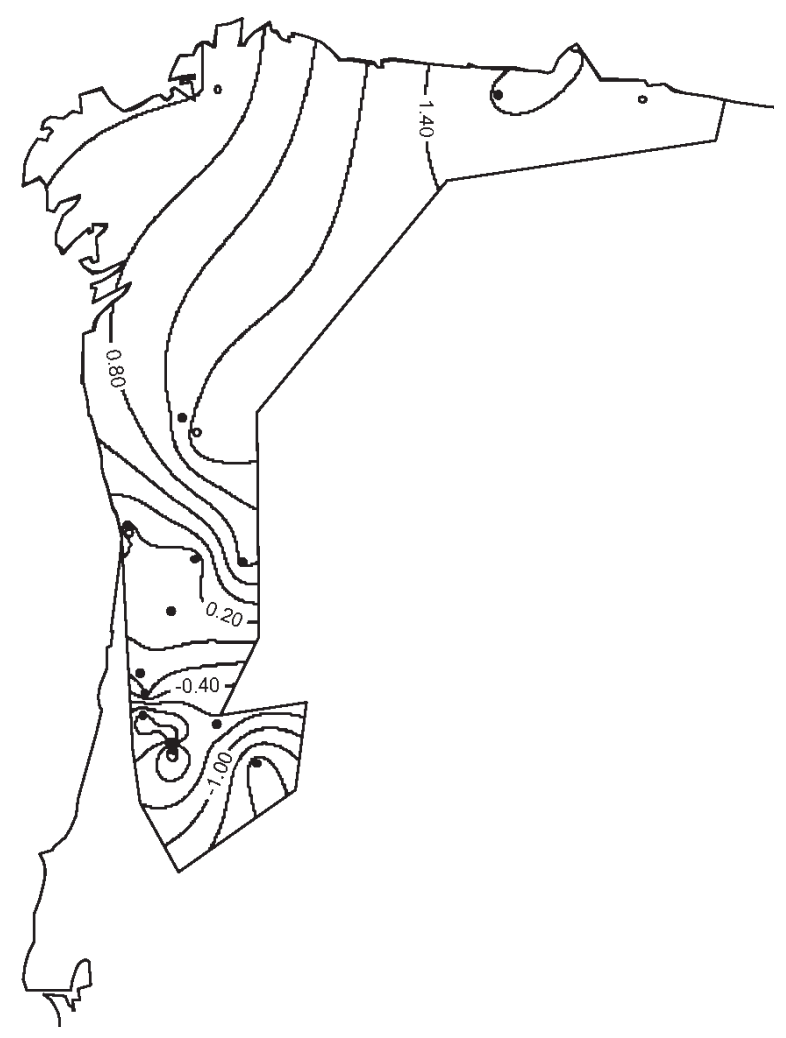

Fig. 6. Trend surface map generated by the kriging of mean factor scores of the first Principal Component axis of 18 populations of female Chioglossa lusitanica.

consistent with documented genetic differentiation. Group 1, from south of the Mondego river in Portugal, is characterised by shorter digits than group 2, from north of the Mondego. A pattern of south to north clinal variation with increasing limb, toe and finger length was found superimposed on this dichotomy, resulting in stepped clines for each of the characters describing appendage size. We suggest that both historical, vicariant isolation and selection processes account for the observed variation. Short appendages, with a low volume to surface ratio, may represent an adaptation to xeric (i.e. less moist) environments (Nevo, 1972; Lee, 1993). Chioglossa lusitanica is a terrestrial streamside salamander extremely dependent on moist habitats and indeed the level of annual precipitation is the main predictor of its range in Portugal (Teixeira et al., 2001; Arntzen and Teixeira, 2006). Given that southern populations appear to occupy a more xeric environment than northern populations (Arntzen and Alex- andrino, 2004) and assuming that rainfall gradients in the past paralleled those of today, selection could have produced the documented (stepped) clines. The general pattern of contemporary restricted gene flow between populations of $C$. lusitanica recently revealed by microsatellite data (F. Sequeira et al., unpublished data) would favour local adaptation along selection gradients, originating the observed morphological pattern of latitudinal variation. The action of either selection or stochastic drift, or both, associated with vicariant isolation may have originated the stepped clines at appendage size, across the Mondego.

Neither colour pattern nor colour pattern variability was associated with group membership or with geographic distances between populations. However, colour pattern variability was higher within the group 1-2 contact zone than elsewhere, suggesting that the mixing of differentiated gene pools increased phenotypical variability. Two more parallels between morphology and genetics were found within group 2 populations. First, a south to north decrease was observed in genetic and colour pattern variability. The processes of sequential bottlenecking and drift invoked to explain the decrease in genetic variation (Alexandrino et al., 2000) appear equally applicable to morphological variation. Secondly, the dominance of the otherwise rare colour type 3 in populations 10 and 11, immediately south of the Douro, may reflect a separate historical refugium in this area, as was suggested by the local presence of unique nuclear and mtDNA alleles (Alexandrino et al., 2000, 2002).

The genetic subdivision of $C$. lusitanica is not matched by an equally pronounced morphological differentiation. Selection operating along environmental gradients appears to be more important in shaping phenotypic diversity than genetic isolation. Cryptic differentiation and clines are phenomena common to many amphibian species (Larson, 1984; Green et al., 1996), streamside salamanders in particular (Good and Wake, 1992; Carlin, 1997; Tarkhnishvili et. al., 2000). For example, C lusitanica and Mertensiella caucasica share ancestry at 14-15 million years before present (Veith et al., 1998) with the further intraspecific genetic differentiation (roughly 1-2 and $\sim 10$ million years before present, respectively) being accompanied by morphological stasis (Alexandrino et al. 2000, present paper; 
Tarkhnishvili et al., 2000). The two species show strong interdependences in ecological, morphophysiological, reproductive and developmental features associated to a streamside life-history (Tarkhnishvili, 1994). In combination with the remarkable evolutionary convergence observed among streamside salamanders, such as $C$. lusitanica and phylogenetically unrelated plethodontid species (e. g., Eurycea longicauda; Wake and Özeti, 1969), this suggests that constraints are in place that prevent departure from a highly specialized morphotype.

\section{Acknowledgements}

This work was supported by the 'Instituto da Conservação da Natureza' (ICN), the 'LIFE' program of the European Community and the 'Fundação para a Ciência e a Tecnologia' (PRAXIS XXI / BD / 5917 / $95 \mathrm{PhD}$ grant to JA and FCT project \# PRAXIS/P/ BIA/11174/1998). Licenses to collect were provided by ICN for Portugal and by the Galician and Asturian 'Junta de Medio Ambiente' for Spain. We thank E. Froufe, C. Oliveira, F. Sequeira, D. Tarkhnishvili and J. Teixeira for support and discussions.

\section{References}

Alexandrino J, Ferrand N, Arntzen JW. 1997. Genetic variation in some populations of the golden-striped salamander, Chioglossa lusitanica (Amphibia: Urodela), in Portugal. Biochem. Genet. 35: 371-381.

Alexandrino J, Froufe E, Arntzen JW, Ferrand N. 2000. Genetic subdivision, glacial refugia and postglacial recolonization in the golden-striped salamander, Chioglossa lusitanica (Amphibia: Urodela). Mol. Ecol. 9: 771-781.

Alexandrino J, Arntzen JW, Ferrand N. 2002. Nested clade analysis and the genetic evidence of population expansion in the phylogeography of the golden-striped salamander, Chioglossa lusitanica (Amphibia: Urodela). Heredity 88: 66-74.

Arntzen JW. 1999. Chioglossa lusitanica Bocage, 1864 - Goldstreifensalamander. In: Grossenbacher K, Thiesmeier B, eds. Handbuch der Amphibien und Reptilien Europas. Wiesbaden: AULA-Verlag, 301-321.

Arntzen JW, Sket B. 1997. Morphometric analysis of black and white European cave salamanders (Proteus anguinus). J. Zool. 241: 699-707.

Arntzen JW, Alexandrino J. 2004. Ecological modelling of genetically differentiated units of the Iberian endemic goldenstriped salamander, Chioglossa lusitanica. Herpetol. J. 14: 137-141.

Arntzen JW, Teixeira J. 2006. History and new developments in the mapping and modelling of the distribution of the golden-striped Salamander, Chioglossa lusitanica. In: Nettmann H-K, Schlüpman M, eds. Areale und Verbreitungsmuster: Genese und Analyse. Bielefeld: Laurenti Verlag, 113-126.

Carlin JL. 1997. Genetic and morphological differentiation between Eurycea longicauda longicauda and E. guttolineata (Caudata: Plethodontidae). Herpetologica 53: 206-217.

Good DA, Wake DB. 1992. Geographic variation and speciation in the torrent salamanders of the genus Rhyacotriton (Caudata: Rhyacotritonidae). University of California Publications in Zoology 126: 1-91.

Green DM, Sharbel TF, Kearsley J, Kaiser H. 1996. Postglacial range fluctuation, genetic subdivision and speciation in the western North American spotted frog complex, Rana pretiosa. Evolution 50: 374-390.

Larson A. 1984. Neontological inferences of evolutionary pattern and process in the salamander family Plethodontidae. In: Hecht MR, Wallace B, Prance GT, eds. Evolutionary Biology 17: 119-217.

Lee JC. 1993. Geographic variation in size and shape of neotropical frogs: a precipitation gradient analysis. Occasional Papers Museum Natural History University Kansas 163: 120.

Manly BFJ. 1996. RT-a program for randomization testing, Version 2.0. Dunedin: Centre for Applications of Statistics and Mathematics, University of Otago.

Nevo E. 1972. Climatic adaptation in size of the green-toad, Bufo viridis. Isr. J. Med. Sci. 54: 1010.

Puorto G, Salomão MG, Theakston RDG, Thorpe RS, Warrell DA, Wüster W. 2001. Combining mitochondrial DNA sequences and morphological data to infer species boundaries: phylogeography of lancehead pitvipers in the Brazilian Atlantic forest, and the status of Bothrops pradoi (Squamata: Serpentes: Viperidae). J. Evol. Biol. 14: 527-538.

Reed DH, Frankham R. 2001. How closely correlated are molecular and quantitative measures of genetic variation? A meta-analysis. Evolution 55: 1095-1103.

Schluter D. 2000. The ecology of adaptive radiation. Oxford University Press, New York.

Sequeira F, Alexandrino J, Rocha R, Arntzen JW, Ferrand N. 2005. Genetic exchange across a hybrid zone within the Iberian endemic golden-striped salamander, Chioglossa lusitanica. Mol. Ecol. 14: 245-254.

StatSoft. 1993. STATISTICA for Windows, Release 4.5. StatSoft Inc., Tulsa, USA.

Surfer. 1996. Surfer for Windows (Win32): Surface Mapping System, Version 6.04. Golden Software Inc., Golden, USA.

Tarkhnishvilli DN. 1994. Interdependences between populational, developmental and morphological features of the Caucasian salamander, Mertensiella caucasica. Mertensiella 4: $315-325$.

Tarkhnishvili DN, Thorpe RS, Arntzen JW. 2000. Pre-Pleistocene refugia and differentiation between populations of the Caucasian salamander (Mertensiella caucasica). Mol. Phylogenet. Evol. 14: 414-422.

Teixeira J, Ferrand N, Arntzen JW. 2001. Biogeography of the golden-striped salamander, Chioglossa lusitanica: a field survey and spatial modelling approach. Ecography 24: 618-623. 
Veith M, Steinfartz S, Zardoya R, Seitz A, Meyer A. 1998. A molecular phylogeny of 'true' salamanders (family Salamandridae) and the evolution of terrestriality of reproductive modes. J. Zool. Sys. Evol. Res. 36: 7-16.

Vences M. 1990. Untersuchungen zur Ökologie, Ethologie und geographischen Variation von Chioglossa lusitanica Bocage, 1864. Salamandra 26: 267-297.
Wake DB, Roth G, Wake MH. 1983. On the problem of stasis in organismal evolution. J. Theor. Biol. 101: 211-224.

Wake DB, Özeti N. 1969. Evolutionary relationships in the family Salamandridae. Copeia 1969: 124-137.

Received: 20 October 2005

Accepted: 2 February 2006 
Appendix I - Sample size (N), mean and standard deviation (in parenthesis) for seven morphometric measurements and colour pattern (CP) taken in 18 populations of Chioglossa lusitanica. For character codes see Table 1, for localities see Fig. 1.

\begin{tabular}{|c|c|c|c|c|c|c|c|c|c|c|}
\hline Loca & Sex & $\mathrm{N}$ & SVL & HL & HW & FLL & HLL & TFL & FTL & $\mathrm{P}$ \\
\hline \multirow[t]{2}{*}{1} & Females & 8 & $3.32(2.38)$ & $1.41(0.34)$ & $.70(0.34)$ & $11.85(0.60)$ & $2.67(0.32)$ & $2.14(0.19)$ & $3.14(0.26)$ & \multirow{2}{*}{$2.27(0.65)$} \\
\hline & Males & 2 & $42.31(0.07)$ & $10.98(0.45)$ & $6.66(0.02)$ & $11.51(0.66)$ & $2.55(0.22)$ & $2.04(0.05)$ & $2.85(0.04)$ & \\
\hline \multirow[t]{2}{*}{2} & es & 28 & 45.8 & 11.6 & 6.91 & $12.21(0.37)$ & 46) & $2.50(0.17)$ & $3.56(0.22)$ & \multirow{2}{*}{$.26(0.63)$} \\
\hline & Males & 23 & $44.61(1.57)$ & $11.33(0.33)$ & $6.90(0.25)$ & $12.67(0.30)$ & 13.94 & $2.37(0.15)$ & 8) & \\
\hline \multirow[t]{2}{*}{3} & & 10 & $46.76(2.99)$ & $11.97(0.61)$ & 7.39 & 12.0 & 13.81 & & & \multirow{2}{*}{$2.79(0.94)$} \\
\hline & Males & 10 & $45.73(0.96)$ & $11.62(0.31)$ & $7.32(0.36)$ & $12.26(0.49)$ & $13.92(0.32)$ & $2.34(0.18)$ & $3.46(0.12)$ & \\
\hline \multirow[t]{2}{*}{4} & Females & 11 & 46.1 & 12.0 & $7.20(0.41)$ & 11.8 & 13.62( & $(0.22)$ & 3. & \multirow{2}{*}{$2.21(0.59)$} \\
\hline & Males & 10 & 46.6 & $11.84(0.39)$ & $7.27(0.23)$ & $12.57(0.41)$ & $13.88(0.39)$ & $2.39(0.12)$ & $(0.17)$ & \\
\hline \multirow[t]{2}{*}{5} & & 12 & 46.6 & 76) & 7.13 & 3) & 6) & & & \multirow{2}{*}{$2.41(0.80)$} \\
\hline & Males & 12 & $46.12(1.30)$ & 11.4 & $7.12(0.31)$ & $12.74(0.46)$ & 13.9 & 14) & & \\
\hline \multirow[t]{2}{*}{6} & Feme & 6 & $(3.41)$ & 11.6 & 7.29 & 11.64 & 13.31 & & & \multirow{2}{*}{$3.45(1.43)$} \\
\hline & Males & 7 & $46.56(1.57)$ & $11.75(0.33)$ & $7.16(0.16)$ & 12.58 & $14.07(($ & $(0.13)$ & & \\
\hline \multirow[t]{2}{*}{7} & ; & 8 & ) & ) & l) & 8) & 6) & 8) & & \multirow{2}{*}{$2.95(1.34)$} \\
\hline & $\mathrm{Ma}$ & 17 & 48. & 12. & 7.7 & 13 & 9) & & & \\
\hline \multirow[t]{2}{*}{8} & & 9 & $45.40(2.49)$ & $11.87(0.49)$ & $7.15(0.40)$ & $12.27(0.42)$ & $13.87(0.46)$ & $2.50(0.16)$ & & \multirow{2}{*}{$2.05(0.88)$} \\
\hline & Males & 17 & $44.90(1.02)$ & $11.52(0.27)$ & $6.97(0.35)$ & $12.60(0.43)$ & $13.91(0.65)$ & $2.46(0.17)$ & $3.65(0.29)$ & \\
\hline \multirow[t]{2}{*}{9} & es & 9 & $45.94(2.51)$ & $2.32(0.68)$ & 7.38 (0.39) & $12.21(0.47)$ & $13.66(0.54)$ & 10) & & \multirow{2}{*}{$2.24(0.89)$} \\
\hline & $\mathrm{M}$ & 10 & 4 & ) & ) & 9) & 6) & 4) & & \\
\hline \multirow[t]{2}{*}{10} & & 3 & 47. & 8) & 2) & 13 & 5) & & & \multirow{2}{*}{$2.82(0.64)$} \\
\hline & Males & 9 & 45.5 & 11.88 & 7.24 & 14.0 & (0.49) & 31) & & \\
\hline \multirow[t]{2}{*}{11} & les & 19 & 34) & 11.95 & $7.27(0$ & $12.07(0.82)$ & 14.1 & 2.67( & & \multirow{2}{*}{$2.90(0.32)$} \\
\hline & Males & 7 & $(0.93)$ & 11.64( & $7.40(0$ & $12.44(0.25)$ & 14.1 & 2.68 & & \\
\hline \multirow[t]{2}{*}{12} & Females & 11 & $45.01(1.58)$ & $11.78(0.34)$ & $7.10(0.25)$ & $12.24(0.41)$ & $13.92(0.43)$ & & & \multirow{2}{*}{$2.09(0.42)$} \\
\hline & Males & 23 & 44.0 & 11.39 & $7.11(0.24)$ & 12.4 & 13.8 & $0.12)$ & 3. & \\
\hline \multirow[t]{2}{*}{13} & Females & 10 & 45.60 & $11.82(0.33)$ & $7.23(0.25)$ & $(0.54)$ & $14.06(0.29)$ & 10) & 26) & \\
\hline & Males & 10 & $44.67(0.86)$ & 11.3 & $7.37(0.23)$ & 12. & 13. & 25) & 3. & \\
\hline 15 & & 10 & 43. & ) & 6.9 & & 14 & & & \\
\hline & Males & 6 & $44.13(1.36)$ & $11.43(0.24)$ & $6.87(0.12)$ & $12.69(0.50)$ & $14.30(0.43)$ & $2.70(0.16)$ & & \\
\hline 16 & $\mathrm{Fe}$ & 13 & $46.01(1.86)$ & $12.07(0.44)$ & $7.20(0.37)$ & $12.83(0.41)$ & $14.58(0.54)$ & $2.70(0.21)$ & $4.09(0.27)$ & 0 \\
\hline & Males & 8 & $44.05(1.36)$ & $11.49(0.50)$ & $7.20(0.30)$ & $13.11(0.35)$ & $14.17(0.31)$ & $2.65(0.20)$ & $3.99(0.26)$ & \\
\hline 18 & Females & 10 & 47.87 (1.97) & $11.91(0.36)$ & $7.50(0.58)$ & $12.60(0.39)$ & $14.48(0.56)$ & $2.84(0.10)$ & $4.01(0.15)$ & \\
\hline & Males & 5 & $47.01(0.84)$ & $11.75(0.25)$ & $7.39(0.23)$ & $13.07(0.20)$ & $14.68(0.28)$ & $2.74(0.18)$ & $4.06(0.17)$ & \\
\hline 19 & Females & 6 & $44.63(3.57)$ & $12.05(0.55)$ & $7.20(0.43)$ & $12.94(0.79)$ & $14.77(0.66)$ & $2.81(0.32)$ & $4.05(0.30)$ & 2.00 \\
\hline & Males & 9 & $46.40(1.38)$ & $12.04(0.13)$ & $7.25(0.25)$ & $13.64(0.74)$ & $14.87(0.64)$ & $2.89(0.14)$ & $4.12(0.16)$ & \\
\hline 20 & Females & 3 & $45.72(3.87)$ & $12.14(0.90)$ & $7.12(0.50)$ & $13.26(0.42)$ & $15.00(0.54)$ & $2.71(0.09)$ & $4.04(0.04)$ & 540 \\
\hline & Males & 4 & $43.73(2.75)$ & $11.61(0.80)$ & $6.71(0.22)$ & $13.18(0.85)$ & $14.76(0.42)$ & $2.61(0.19)$ & $3.92(0.21)$ & \\
\hline
\end{tabular}

